\title{
In situ caecal degradation of roughages in horses ${ }^{1}$
}

\author{
Vinícius Pimentel Silva², Fernando Queiroz de Almeida ${ }^{3}$, Eliane da Silva Morgado², Liziana \\ Maria Rodrigues ${ }^{4}$, Tiago Marques dos Santos ${ }^{5}$, Henrique Torres Ventura ${ }^{6}$
}

\author{
${ }^{1}$ Pesquisa financiada pelo CNPq/FAPERJ. \\ 2 Programa de Pós-graduação em Zootecnia - UFRRJ. Bolsista da CAPES \\ 3 Instituto de Veterinária - UFRRJ. Bolsista Pesquisador CNPq. \\ ${ }^{4}$ Graduação em Zootecnia - UFRRJ. Bolsista de Iniciação Científica PIBIC-CNPq/UFRRJ. \\ ${ }^{5}$ Mestrado em Ciências Veterinárias - UFRRJ. Bolsista da CAPES. \\ ${ }^{6}$ Graduação em Zootecnia - UFRRJ. Bolsista de Iniciação Científica FAPERJ.
}

\begin{abstract}
The present study was carried out to evaluate the in situ degradation of dry matter (DM), neutral detergent fiber (NDF) and crude protein (CP) in roughages by the in situ caecal digestion technique in horses. The roughages evaluated were: Lucerne hay (Medicago sativa), peanut (Arachis pintoi cv. Amarillo), desmodio(Desmodium ovalifolium), stylo (Stylosanthes guianensis cv. Mineirão), pigeon pea (Cajanus cajan), lime-yellow pea (Macrotyloma axillare) and coastcross hay (Cynodon dactylon cv. coastcross). The assay was conducted in a complete randomized design with seven roughages and three replications. One mare with a cannula fitted in the caecum was used, fed diet consisting of coastcross hay ( $80 \%)$ and concentrate $(20 \%)$ at $2.0 \% \mathrm{BW}$, four times a day. Nylon $6.5 \times 20 \mathrm{~cm}$ bags were used with $45 \mu /$ pore, containing $5.2 \mathrm{~g}$ $\mathrm{DM} / \mathrm{bag}$, inserting 3 or 4 bags in the caecum at the times of 2, 4, 6, 8, 12, 24 and 48 hours incubation. The caecum in situ degradability parameters of nutrients were obtained by Ørskov model. The DM degradability parameters of all the roughages were significant. There was no fit to the model for pigeon pea for CP and NDF and desmodio. Peanut, stylo and lime-yellow pea presented larger potentially degradable DM with values of 53, 46.5 and 40\%, respectively, and higher values for the soluble fraction of $20,21,28.6 \%$, with high degradability rates of $10.36,20.26$ and $14.8 \% \mathrm{~h}^{-1}$. Higher NDF degradation rates were observed in these foodstuffs with values of 9.1 and $11.3,11.2 \% \mathrm{~h}^{-1}$, high potentially degradable fraction with values of 55, 51.8 and $47.2 \%$, and greater CP degradation at 48 hours with values of 87,95 , and $94.8 \%$. Peanut, stylo and lime-yellow pea presented potential for use in horses diets.
\end{abstract}

Key Words: cannula, digestion, fiber, forage, legume

\section{Degradação cecal in situ de alimentos volumosos em equinos}

RESUMO - Objetivou-se avaliar a degradação da matéria seca (MS), fibra em detergente neutro (FDN) e proteína bruta de alimentos volumosos pela técnica da digestão cecal in situ em equinos. Avaliaram-se as forrageiras: feno de alfafa (Medicago sativa), amendoim forrageiro (Arachis pintoi cv. Amarillo), desmódio (Desmodium ovalifolium), estilosantes (Stylosanthes guianensis cv. Mineirão), guandu (Cajanus cajan), macrotiloma (Macrotyloma axillare) e feno de coastcross (Cynodon dactylon cv. coastcross). O ensaio teve duração de 35 dias e foi realizado em delineamento inteiramente casualizado com sete alimentos e três repetições. Utilizou-se uma égua fistulada no ceco, alimentada com dieta composta por feno de coastcross $(80 \%)$ e concentrado (20\%), fornecida quatro vezes ao dia em quantidade equivalente a $2 \%$ do peso vivo. No ceco, foram inseridos 3 a 4 sacos de náilon de porosidade $45 \mu$ de $6,5 \times 20 \mathrm{~cm}$, contendo $5,2 \mathrm{~g}$ de $\mathrm{MS} / \mathrm{saco}$, nos tempos de 2, 4, 6, 8, 12, 24 e 48 horas de incubação. Os parâmetros de degradação da MS de todos os volumosos foram significativos. Não houve ajuste no modelo de degradação da PB e FDN do guandu. O amendoim, estilosantes e macrotiloma apresentaram maior fração potencialmente degradável da MS, com valores de 53, 46,5 e 40\%, respectivamente, e os maiores valores da fração solúvel de 20,21, 28,6\%, além de elevadas taxas de degradação $\left(10,36,20,26\right.$ e 14,8\% $\left.\mathrm{h}^{-1}\right)$. Nestes alimentos, também foram observadas as maiores taxas de degradação da $\operatorname{FDN}\left(9,1\right.$ e $\left.11,3,11,2 \% \mathrm{~h}^{-1}\right)$, das frações potencialmente degradáveis $(55,51,8$ e 47,2\%) e as mais altas taxas de degradação da PB em 48 horas de incubação (87, 95, 94,8\%, respectivamente). O amendoim forrageiro, o estilosantes e o macrotiloma apresentam potencial de uso nas dietas para equinos.

Palavras-chave: cânula, digestão, fibra, forrageiras, leguminosa 


\section{Introduction}

Horses are naturally herbivorous and the fiber of roughages has fundamental importance in promoting the normal digestive function (Moore-Colyer et al., 2003) and preventing behavioral disorders (NRC, 2007). The knowledge of horse nutrition has followed the feed evaluation techniques applied to other species (Hyslop et al., 2006). The in situ technique was first developed for swine, applied to ruminants, and then methodological adaptation for horses allowed assessment of the dynamic of feed degradation at segments of the horse's gastrointestinal tract (Koller \& Hintz, 1978; Udén \& Van Soest, 1984; Miraglia et al., 1988; Moore-Colyer et al., 2002; Hyslop, 2006).

The characterization of the degradation profile can be a useful indicator for nutritional value, especially for components of the fiber fraction (Stefansdottir et al., 1996). In situ degradation has advantages over total feces collection, because it uses small amounts of the feed in porous bags that are incubated in the horse caecum or colon. The value of the nutrients lost over time in the bags is associated to the degradation model proposed by Ørskov \& McDonald (1979).

Degradation rate and the extent of degradation over time are parameters obtained through the model and define the speed that the nutrient is digested and losses from it until the maximum point is reached. These parameters are essential to understand the degradation kinetic in different segments of the gastrointestinal tract, and consequently to determine the nutrient proportion that was available for absorption over time. The in situ technique results in information about the nutrient availability in different parts of the equine gastrointestinal tract, and can be use to increase precision in diet formulations and choose the feed based on nutrient degradation (Moore-Colyer et al., 2002).

The objective of the present experiment was to evaluate the nutritional composition and in situ caecal degradation of roughages in horses.

\section{Material and Methods}

The experiment was conducted in the Equine Health Research Laboratory of Veterinary Institute, and feed analysis was carried out in the laboratories of the Animal Science Institute at the Universidade Federal Rural do Rio de Janeiro, Brazil.

The experiment was conducted in a completely randomized design with seven roughages and three replications. The roughages evaluated were: Lucerne hay (Medicago sativa), peanut (Arachis pintoi cv. Amarillo), desmodio (Desmodium ovalifolium), stylo (Stylosanthes guianensis cv. Mineirão), pigeon pea (Cajanus cajan), lime-yellow pea (Macrotyloma axillare) and coastcross hay (Cynodon dactylon cv. coastcross) (Table 1).

The samples of peanut, desmodio, stylo, pigeon pea and lime yellow pea were collected at the Pasture Sector of Animal Science Institute at the Universidade Federal Rural do Rio de Janeiro and were 60 to 90 days old. The coastcross hay and lucerne hay were purchased locally.

One 5-year-old crossbreed mare was used with $210 \mathrm{~kg}$ BW. The mare was fitted with a cannula in the caecum, according to Lowe et al. (1970). The cannula was cleaned twice a day, in the morning and afternoon. The animal was kept in an individual stall with water and mineral salt ad libitum. The animal was weighted before the experiment to adjust the feed intake. The diet was given considering the individual daily intake of $2 \% \mathrm{BW}$, on the dry matter basis according to the NRC (1989), for daily maintenance requirements for horses with $200 \mathrm{~kg} \mathrm{BW}$. The diet consisted of coastcross hay ( $80 \%$ ) and commercial concentrate (20\%) (Table 2), fed at the same time, four times a day, at 7 a.m., midday, 5 p.m. and 9 p.m.

The assay was carried out during 35 days and in situ techniques were adapted from procedures described by Huntington \& Givens (1995). Nylon $6.5 \times 20 \mathrm{~cm}$ bags were used with $45 \mu$ /pore, with $5.2 \mathrm{~g} \mathrm{DM}$ roughages/bag, in a $20 \mathrm{mg} / \mathrm{cm}^{2}$ ratio(Hyslop et al., 1999). Each bag was firmly sealed and in the top end was fixed to a $40 \mathrm{~cm}$ long $45 \mathrm{~mm}$ nylon rope.

Table 1 - Nutritional composition of roughages, on dry matter basis

\begin{tabular}{|c|c|c|c|c|c|c|c|}
\hline Nutrient & Lucerne hay & Peanut & Desmodio & Stylo & Pigeon pea & Lime-yellow pea & Coastcross hay \\
\hline Dry matter (\%) & 88.9 & 24.5 & 30.9 & $\begin{array}{c}33.1 \\
\text { dry ma }\end{array}$ & 34.8 & 17.2 & 85.9 \\
\hline Organic matter & 91.6 & 92.1 & 94.9 & 93.8 & 95.6 & 94.4 & 95.1 \\
\hline Crude protein & 17.6 & 18 & 14 & 16.2 & 20.3 & 19.1 & 6.3 \\
\hline Ether extract & 1.4 & 1.9 & 2.6 & 5.6 & 4.1 & 2.1 & 1.5 \\
\hline Neutral detergent fiber & 64.5 & 46.8 & 52.5 & 47.5 & 56.9 & 38.2 & 82.9 \\
\hline Acid detergent fiber & 43.7 & 30.7 & 32.9 & 33.3 & 28.5 & 26.3 & 39.8 \\
\hline Celullose & 30.7 & 18.7 & 23.4 & 23.4 & 15.5 & 18.9 & 16.1 \\
\hline Lignin & 8.3 & 12.4 & 8.9 & 9.6 & 12.6 & 7.4 & 4.0 \\
\hline
\end{tabular}


Table 2 - Composition of coastcross hay and concentrate, on dry matter basis

\begin{tabular}{lrc}
\hline Composition & Coastcross hay & Concentrate \\
\hline Dry matter (\%) & 88.4 & 88.7 \\
Organic matter (\%) & 93.8 & 82.8 \\
Crude protein (\%) & 11.9 & 11.1 \\
Ether extract (\%) & 1.3 & 3.7 \\
Neutral detergent fiber (\%) & 67.2 & 44.8 \\
Acid detergent fiber (\%) & 31.4 & 18.4 \\
Lignin (\%) & 2.4 & 1.6 \\
Gross energy (Mcal/kg DM) & 3.49 & 3.45 \\
\hline
\end{tabular}

Three or four bags were placed in the caecum at every incubation time, beginning always at 9 a.m.. The bags were incubated according to Hyslop (2006), for 0, 2, 4, 6, 12, 24 and 48 hours.

The bags were previously moistened in distilled water at ambient temperature for one minute, to avoid fluctuation inside the caecum. When each incubation time was over, the bags were removed from the caecum and frozen at $-20^{\circ} \mathrm{C}$ until the end of the incubation period, and then they were thawed and washed. They were washed gently by hand until there was no residue in running water that showed that the impregnations were removed. The lost content at time zero was obtained subjecting three bags of each feed to the same washing procedure. The bags were dried in forced-air oven for 48 hours at $55^{\circ} \mathrm{C}$. The bags were weighed and the corresponding samples of each feed and from the same incubation time were mixed and homogenized.

The in situ caecal degradation of the dry matter, neutral detergent fiber and crude protein were estimated by the model proposed by Ørskov \& McDonald (1979): $\mathrm{d}=\mathrm{a}+\mathrm{b}\left(1-\mathrm{e}^{-\mathrm{c}^{*} \mathrm{t}}\right) ; \mathrm{d}=$ degradation through time ' $\mathrm{t}$ '; $\mathrm{a}=$ soluble fraction, and curve interception; $b=$ insoluble fraction potentially degradable; $c=$ degradation rate of ' $b$ '; $\mathrm{t}=$ incubation time.

At the end of the experiment, the feeds and residue samples were analyzed to determine the percentage of dry matter (DM), crude protein (CP) and neutral detergent fiber (NDF), according to the AOAC (1990) and Van Soest et al. (1991). The degradation parameters were adjusted by nonlinear regression, using the Statistics and Genetics Analysis-SAEG software (UFV, 2000). The mean values of maximum degradation in 48 hours $\left(\mathrm{D}_{48}\right)$ were compared by Student Newman-Keuls test (5\%).

\section{Results and Discussion}

Observed parameters values of dry matter in all the evaluated roughages were significant $(\mathrm{P}<0.01)$, but there was no model adjustment for pigeon-pea crude protein and neutral detergent fiber (Table 3). There was no significant ' $a$ ' parameter in the degradation model of neutral detergent fiber for desmodio and lime-yellow pea.

According to Ørskov (2000), a longer incubation period to fit the model would be needed for these feeds because there was a difference greater than $10 \%$ between the last two incubation times, making the parameters non-significant. The models presented high determination coefficients, confirming the fit and describing the caecal degradation profile of roughage nutrients over time.

The feeds that presented higher dry matter ' $b$ ' fraction were the peanut, stylo, lime-yellow pea and Lucerne hay, with values of $53 ; 46.5 ; 40$ and $38.5 \%$, respectively. It suggested that higher observed values in this ' $b$ ' parameter

Table 3 - Estimative of parameters of caecal degradation of DM, NDF, CP, and 48 hours roughage degradation

\begin{tabular}{|c|c|c|c|c|c|c|c|c|}
\hline Nutrient & Parameter & Lucerne & Peanut & Desmodio & Stylo & Pigeon pea & Lime yellow pea & Coastcross hay \\
\hline $\mathrm{DM}$ & $\begin{array}{c}\mathrm{a}(\%) \\
\mathrm{b}(\%) \\
\mathrm{c}\left(\% \mathrm{~h}^{-1}\right) \\
\mathrm{D}_{48} 1(\%) \\
\mathrm{R}^{2}(\%\end{array}$ & $\begin{array}{c}23.62^{* * *} \\
38.55^{* * *} \\
13.80^{* *} \\
62.1 \mathrm{~B} \\
97.0\end{array}$ & $\begin{array}{c}29.57^{* * *} \\
53.05^{* * *} \\
10.36^{* *} \\
82.2 \mathrm{~A} \\
96.9\end{array}$ & $\begin{array}{c}31.81^{* * *} \\
34.02^{* * *} \\
5.10^{* * *} \\
62.8 \mathrm{~B} \\
99.3\end{array}$ & $\begin{array}{c}30.27^{* * *} \\
46.55^{* * *} \\
14.82^{* *} \\
76.7 \mathrm{~A} \\
96.0\end{array}$ & $\begin{array}{c}24.36^{* * *} \\
26.53^{* * *} \\
6.78^{* * *} \\
49.8 \mathrm{C} \\
99.3\end{array}$ & $\begin{array}{c}39.68^{* * *} \\
40.32^{* * *} \\
20.26^{* * *} \\
80.0 \mathrm{~A} \\
98.9\end{array}$ & $\begin{array}{c}16.71^{* * *} \\
31.43^{* * *} \\
7.12^{* * *} \\
47.1 \mathrm{C} \\
99.7\end{array}$ \\
\hline $\mathrm{NDF}$ & $\begin{array}{c}\mathrm{a}(\%) \\
\mathrm{b}(\%) \\
\mathrm{c}\left(\% \mathrm{~h}^{-1}\right) \\
\mathrm{D}_{48}{ }^{2}(\%) \\
\mathrm{R}^{2}\end{array}$ & $\begin{array}{c}7.74^{*} \\
38.02^{* * *} \\
7.01^{* * *} \\
44.4 \mathrm{C} \\
96.1\end{array}$ & $\begin{array}{c}14.29 * * * \\
55.05^{* * *} \\
9.16^{* *} \\
68.6 \mathrm{~A} \\
96.5\end{array}$ & $\begin{array}{c}2.76 \mathrm{NS} \\
44.71^{* * *} \\
3.76^{*} \\
40.1 \mathrm{C} \\
97.2\end{array}$ & $\begin{array}{c}5.11 * \\
47.22 * * * \\
11.37^{* * *} \\
52.1 \mathrm{~B} \\
98.1\end{array}$ & $\begin{array}{c}3.92 \mathrm{NS} \\
38.33 \mathrm{NS} \\
2.16 \mathrm{NS} \\
28.6 \mathrm{D} \\
78.3\end{array}$ & $\begin{array}{c}0.07 \mathrm{NS} \\
51.84^{* * *} \\
11.28^{* * *} \\
51.6 \mathrm{~B} \\
98.2\end{array}$ & $\begin{array}{c}10.70 * * * \\
34.39 * * * \\
5.75^{* * *} \\
42.9 \mathrm{C} \\
99.4\end{array}$ \\
\hline $\mathrm{CP}$ & $\begin{array}{c}\mathrm{a}(\%) \\
\mathrm{b}(\%) \\
\mathrm{c}\left(\% \mathrm{~h}^{-1}\right) \\
\mathrm{D}_{48}{ }^{3}(\%) \\
\mathrm{R}^{2}\end{array}$ & $\begin{array}{c}33.00^{* * *} \\
55.49^{* * *} \\
17.65^{* *} \\
88.4 \mathrm{C} \\
95.3\end{array}$ & $\begin{array}{c}19.59^{* *} \\
68.12^{* * *} \\
9.53^{* *} \\
87.0 \mathrm{D} \\
96.5\end{array}$ & $\begin{array}{c}31.56^{* * *} \\
53.14^{* *} \\
2.67^{*} \\
69.9 \mathrm{~F} \\
97.0\end{array}$ & $\begin{array}{c}32.38^{* * *} \\
62.72^{* * *} \\
19.09^{* * *} \\
94.8 \mathrm{~B} \\
97.3\end{array}$ & $\begin{array}{c}12.51^{* *} \\
90.00 \mathrm{NS} \\
1.85 \mathrm{NS} \\
65.4 \mathrm{E} \\
96.3\end{array}$ & $\begin{array}{c}41.05^{* * *} \\
53.83^{* * *} \\
28.68^{* * *} \\
95.0 \mathrm{~A} \\
99.7\end{array}$ & $\begin{array}{c}28.83^{* * *} \\
35.66^{* * *} \\
9.29^{* * *} \\
64.0 \mathrm{G} \\
98.6\end{array}$ \\
\hline
\end{tabular}

Significance of degradation parameter model: *** $(\mathrm{P}<0.001) ; * *(\mathrm{P}<0.01) ; *(\mathrm{P}<0.05) ; \mathrm{NS}(\mathrm{P}>0.05)$.

Means followed by the same letter on the line do not differ by the SNK test at $5 \%$.

${ }^{1} \mathrm{CV} \%=5.2 \% ;{ }^{2} \mathrm{CV} \%=3.9 \% ;{ }^{3} \mathrm{CV} \%=1.4 \%$. 
develop higher amounts of potentially available nutrients to be absorbed in the horse gastrointestinal tract.

The $\mathrm{D}_{48}$ dry matter degradation observed was higher $(\mathrm{P}<0.05)$ in peanut, lime-yellow pea and stylo, with values of $82.2,80.0$ and $76.7 \%$, respectively. Fiber from roughages represents the biggest amount of dry matter, therefore the degradation parameters that define the kinetic profile curve are due to the fiber fraction.

In the present experiment, the results indicated that roughage composition had an effect on caecal dry matter degradation, similar to that observed by Hyslop et al. (1999), because depending the roughage type, the fiber fraction was different not only in the amount degraded, represented by the potentially degradable ' $b$ ' fraction and by maximum degradation in 48 hours $\left(\mathrm{D}_{48}\right)$, but also the rate that occurred represented by the 'c' parameter (Figure 1).

Koller \& Hintz (1978) compared the dry matter in situ degradation of lucerne in equine caecum and bovine rumen and observed $90.4 \%$ caecal degradation in 48 hours maximum time. It was hoped that lucerne would present higher degradation potential, but the lucerne hay in the experiment was at the advanced maturity stage, with neutral detergent fiber, acid detergent fiber and lignin values respectively of 64,43 and $8.3 \%$, that reduced lucerne hay dry matter degradation to $62 \%$.

According to Veloso et al. (2006), bush legumes, such as pigeon pea, present higher proportions of antinutritional substances in their composition. Thus, the tannin and lignin(Van Soest, 1994; Broderick, 1995; Veloso et al., 2006) probably reduced the dry matter degradation that reached $49.8 \%$ in 48 hours of incubation.

The grass presented different anatomical and chemical composition than the legumes, especially the form of lignin deposition (Jung \& Allen, 1995). Furthermore, the highest passage rate of digesta from horses (Welyenberg et al., 2006) reduced bacterial colonization time, reduced the degradation process and thus justified the lower $\mathrm{D}_{48}$ value observed for coastcross hay of $47.1 \%$. This also was observed by Koller \& Hintz (1978) who reported better ruminal bacteria degradation by the in situ technique, compared to those in the horse colon, and observed lower ' $b$ ' fraction degradation from dry matter in horses compared to ruminants at the same incubation time.

Moore-Colyer et al. (2002) observed in ponies that effective caecal degradation of grass dry matter at 40 and 60 hours of incubation reached values of 43.1 and $47.9 \%$, respectively, while Hyslop (2006) observed 47 to $67 \%$ grass dry matter degradation.

According to Morgado et al. (2009), carbohydrates breakdown in the roughages showed high amount of carbohydrates that were rapidly fermentable in the legume composition: peanut, lime yellow pea and stylo with respectively 20, 28.6 and $21 \%$ in dry matter. These constituents were also partially responsible for high ' $\mathrm{c}$ ' degradation rate in the DM of $10.36,20.26$ and $14.8 \% \mathrm{~h}^{-1}$, respectively, because the bacteria rapidly degraded them. In this case, the lucerne hay ' $\mathrm{c}$ ' parameter was high at $13.8 \% \mathrm{~h}^{-1}$, although it presented $5.2 \%$ of rapidly fermentable carbohydrates (Morgado et al., 2009), indicating that not only the rapidly fermentable carbohydrates determined the degradation rate.

The $\mathrm{D}_{48}$ of neutral detergent fiber was highest $(\mathrm{P}<0.05)$ in peanut with $68.6 \%$, and there was no difference between lime yellow pea and stylo with 51.6 and 52.1, respectively. According to Hoffman et al. (2001), neutral detergent fiber analysis is especially based on plant cellular structure, that corresponds to the slowly fermentable carbohydrates in horse feed. Therefore, there is a degradation rate associated to this fraction, and it is important to measure it.

Considering that the transit time of digesta in horses presents a fast passage rate in the caecum-colon compared to the rumen-reticulum in ruminants (Welyenberg et al., 2006) there will be less time for microbial action. Therefore, it is important to maximize the fermentation process through roughages that present NDF with better degradation profile. The highest neutral detergent fiber ' $c$ ' values were observed in stylo, lime yellow pea, peanut and lucerne hay with $11.3 ; 11.2,9.1$ and $7 \% \mathrm{~h}^{-1}$, respectively

Desmodio presented 'c' value of $3.7 \% \mathrm{~h}^{-1}$ and, according to Pérez et al. (2002) desmodio presents a high tannin value that interferes negatively in protein degradation and dry matter degradability and reduced bacterial activity.

The neutral detergent fiber ' $c$ ' parameter can become referential to estimate fiber quality, consequently, identifying feed that are rapidly digested in the large intestine. In ruminants, the highest ruminal fiber degradation rates influence intake, allowing higher DM inflow into the gastrointestinal tract (Orskov, 2000). In horses, there are few studies in this area, and the 'c' parameter from degradation models to predict intake might not be viable for use, because the anatomic disposition of the gastrointestinal tract is different. Associated to the ' $c$ ' parameter is the ' $b$ ' parameter, with higher value for peanut, lime yellow pea and stylo, 55, 51.8 and $47.2 \%$, respectively, so this legumes might be considered with high fermentation potential.

Coastcross hay presented lower potentially degradable neutral detergent fiber fraction, of $34.3 \%$, compared to the other roughages evaluated. According to Jung \& Allen (1995), the grasses are different regarding fiber polysaccharides composition and lignin deposition in the cellular wall. 

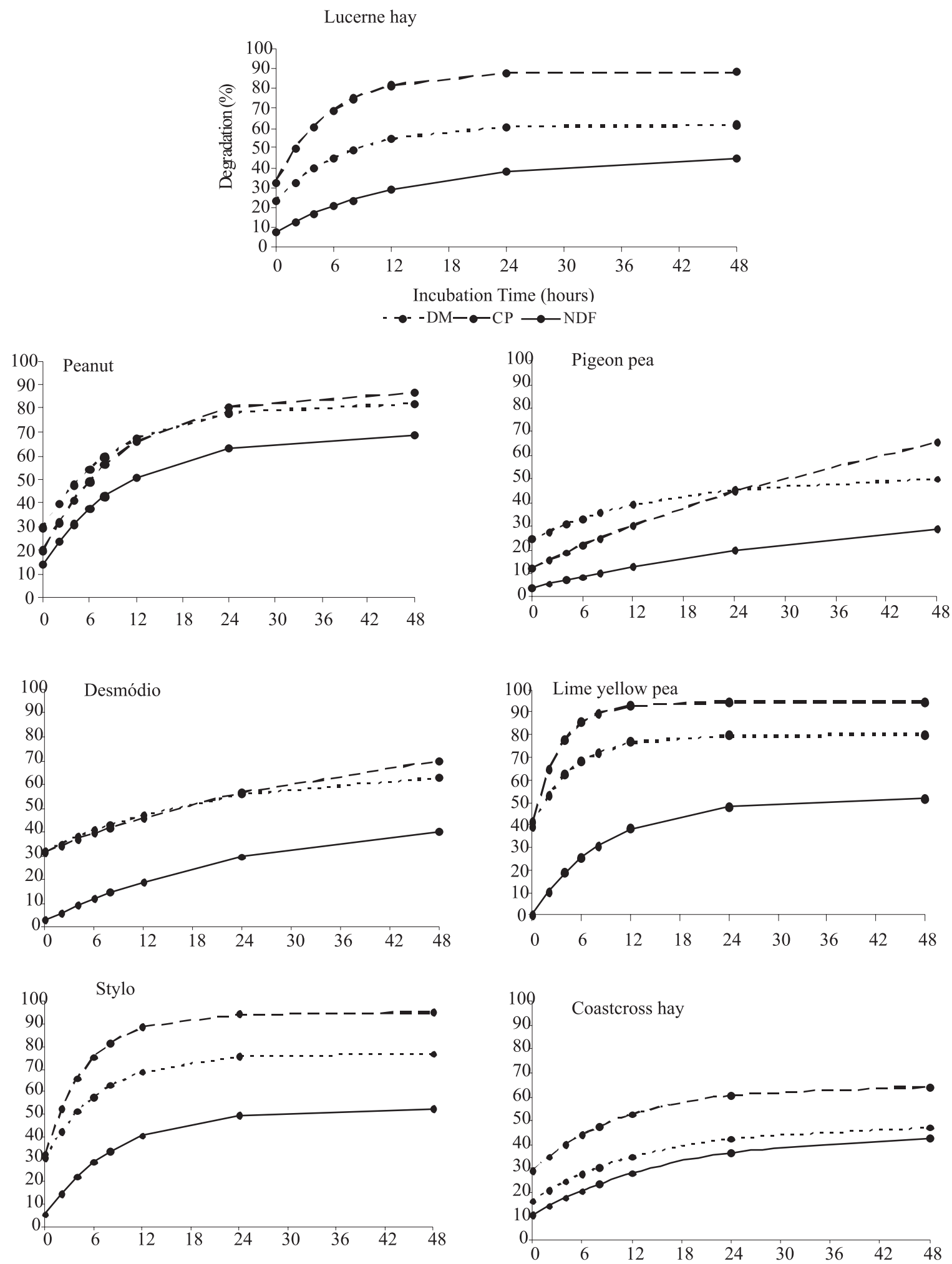

Figure 1 - In situ caecal degradation of roughage nutrients.

However, it must be considered that the coastcross hay used in this experiment was at the advanced maturity stage.

Hyslop (2006) reviewed the mobile bags technique associated to horse degradation models and showed that effective neutral detergent fiber degradation of lucerne bags inserted in the caecum and recovered in the feces varied from 20 to $40 \%$, while lucerne hay neutral detergent fiber varied from 14 to $40 \%$, close values to those observed in the present study for the maximum degradation time. 
In horses, according to digestive tract disposition, protein digestion is initially enzymatic and occurs in the small intestine followed by fermentative digestion in the large intestine (NRC, 2007). Therefore, proteins that pass through the ileum, such as the nitrogen from urea hydrolysis (Van Soest, 1994; Frape, 1998) are factors that contribute to dietetic fiber degradation.

The $\mathrm{D}_{48}$ of protein from the roughages was higher $(\mathrm{P}<0.05)$ for lime yellow pea, stylo, lucerne hay and peanut, with values of $95,94.8,88.4$ and $87 \%$ respectively, demonstrating that a large amount of protein present in these roughages was used for the bacterial growth, and in lime yellow pea, stylo, lucerne hay and peanut degradation occurred rapidly at the high degradation rates of 28.6, 19.0, 17.6 and $9.5 \% \mathrm{~h}^{-1}$, respectively.

According to NRC (2007) there is no evidence regarding significant amino acid absorption from bacterial synthesis in the large intestine. However, evaluation of protein degradation from roughage in the caecum showed protein quality and proteolyses activity in the large intestine.

The lime yellow pea presented higher parameters of crude protein degradation because it was harvested while in vegetative growth, presenting a higher proportion of leaves. This fact conferred high protein solubility of $41 \%$. The peanut presented lower protein solubility, of $19.5 \%$, compared to other roughages evaluated in this experiment. The lime yellow pea and stylo had the best parameters for crude protein degradation of all roughages.

The caecal degradation profile curves for crude protein indicated that in some cases, part of the protein would be unavailable to small intestine absorption. Pigeon pea presented $22 \%$ crude protein in DM but presented lower crude protein degradation and solubility values, of $65 \%$ and $12.5 \%$, respectively. According to Malafaia et al. (1997), crude protein can be fractionated to better characterize, with fraction $B_{3}$ the insoluble protein in neutral detergent, and Ribeiro et al. (2001), suggested lower digestion rates of fraction $\mathrm{B}_{3}$.

Veloso et al. (2006) observed that pigeon pea presented a lower ruminal degradation with insoluble nitrogen content in acid detergent of $26.2 \%$ from total nitrogen, with negative correlation associated to insoluble acid detergent nitrogen levels, and with degradation components from fiber fraction. Pigeon pea presented lower degradation and crude protein degradation rate compared to other legumes, even with higher protein content. There may have been a higher protein amount attached to the fiber fraction of the slow degradation rate. Therefore there was lower neutral detergent fiber degradation of $28.6 \%$ for the same incubation time.
Due to low ' $c$ ' parameters, the rates of 1.85 and $2.16 \% \mathrm{~h}^{-1}$ in crude protein and neutral detergent fiber models observed, respectively, in pigeon pea, there was no fit to the degradation model for these nutrients. The pigeon pea and desmodio were usually the legumes that presented the lowest caecal degradation rates, and with slow availability of nutrients. This evidence was sustained by the highest neutral detergent fiber content, 56.9 and $52.5 \%$ and lignin of 12.6 and $8.9 \%$, respectively. According to Broderick (1995), in different legumes, condensed tannin presence results in lower rates of protein degradation.

The protocol for the in situ experiment followed the recommended patterns of previous studies in horses (Hyslop et al., 1999). Kinetic degradation studies of nutrients are recent in equine nutrition and there are a few studies for comparison. In the in situ technique used for ruminants, the ruminal environment must be in perfect conditions allowing the maximum degradation profile (Ørskov, 2000). This condition is also valid for horse caeca-colon. According to Clarke et al. (1990), the equine large intestine presents a fermentation cycle associated to the meals, so that when there is a big interval between meals, microbial activity decreases and in this way, fermentative activity from the microorganisms in the large intestine decreases. In the present experiment, the feed was fractionated in four equal daily meals, distributed in 24 hours, providing homogeneous intake flow and higher uniform fermentative environment.

There should be more experiments carried out to make the technique viable and reach better comparisons, because Miraglia et al. (1998) observed significant correlation between dry matter in vivo digestion with total feces collection and in situ digestion values using nylon bags inserted in the caecum.

\section{Conclusions}

Peanut (Arachis pintoi cv. Amarillo), stylo (Stylosanthes guianensis cv. Mineirão) and lime yellow pea (Macrotyloma axillare) presented high in situ caecal degradation of their nutrients and they have potential for use in horse diets. Peanut fiber degradation was higher than the other tropical legumes, similarly to its protein content, and pigeon pea presented lower nutrient availability, according to the lowest nutrient degradation values. Lucerne hay presented degradation parameters higher than coastcross hay, and dry matter caecal degradation, neutral detergent fiber and crude protein values of $13.8,7.0$ and $17.6 \% \mathrm{~h}^{-1}$, respectively, showing higher nutrient availability. 


\section{References}

ASSOCIATION OF OFFICIAL ANALYTICAL CHEMISTS AOAC. Official methods of analysis. 15.ed. Washington, D.C., 1990. 1141p.

BRODERICK, G.A. Desirable characteristics of forage legumes for improving protein utilization in ruminants. Journal of Animal Science, v.73, n.9, p.2760-2773, 1995.

CLARKE, L.L.; ROBERTS, M.C.; ARGENZIO, R.A. Feeding and digestive problems in horses: physiologic responses to a concentrated meal. Veterinary Clinics of North America: Equine Practice, v.6, n.2, p.433-450, 1990.

FRAPE, D. Equine nutrition and feeding. 2.ed. Victoria: Blackwell, 1998. 564p.

HOFFMAN, R.M.; WILSON, J.A.; KRONFELD, D.S. et al. Hydrolysable carbohydrates in pasture, hay, and horse feeds: Direct assay and seasonal variation. Journal of Animal Science, v.79, p.500-506, 2001.

HUNTINGTON, J.A.; GIVENS, D.L. The in situ technique for studying the rumen degradation of feeds: a review of the procedure. Nutrition Abstracts and Reviews (Series B), v.65, n.2, p.63-93, 1995.

HYSLOP, J.J. In situ and mobile bag methodology to measure the degradation profile of processed feeds in different segments of the equine digestive tract. Livestock Production Science, v.100, p.18-32, 2006.

HYSLOP, J.J.; STEFANSDOTTIR, G.J.; MCLEAN, B.M.L. et al. In situ incubation sequence and its effect on degradation of food components when measured in the caecum of ponies. Animal Science, v.69, p.147-156, 1999.

JUNG, H.G.; ALLEN, M.S. Characteristics of plant cell walls affecting intake and digestibility of forages by ruminants. Journal of Animal Science, v.73, p.2774-2790, 1995.

KOLLER, B.L.; HINTZ, H.F.; ROBERTSON, J.B. et al. Comparative cell wall and dry matter digestion in the caecum of the pony and the rumen of the cow using in vitro and nylon bag techniques. Journal of Animal Science, v.47, n.1, p.209-215, 1978.

LOWE, J.E.; HINTZ, H.F.; SCHRYVER, H.F. A new technique for long-term cecal fistulation in ponies. American Journal of Veterinary Research, v.31, n.6, p.1109-1111, 1970.

MALAFAIA, P.A.M.; VALADARES FILHO, S.C.; VIEIRA, R.A.M. et al. Determinação e cinética ruminal das frações protéicas de alguns alimentos para ruminantes. Revista Brasileira de Zootecnia, v.26, n.6, p.1243-1251, 1997.

MIRAGLIA, N.; MARTIN-ROSSET, W.; TISSERAND, J.L. Mesure de la digestilité des fourrages destinés aux chevaux par la technique des sacs de nylon. Annales de Zootechnie, v.37, n.1, p.12-20, 1988.

MOORE-COLYER, M.J.S.; HYSLOP, J.J.; LONGAND, A.C. et al. Degradation of four dietary fiber sources by ponies as measured by ponies as measured by the mobile bag technique. In: EQUINE NUTRITION AND PHYSIOLOGY SOCIETY SYMPOSIUM, 18., 2003, Michigan. Proceedings... Michigan: ENPS, 2003. p.153-154.

MOORE-COLYER, M.J.S.; HYSLOP, J.J.; LONGLAND, A.C. et al. The mobile bag technique as a method for determining the degradation of four botanically diverse fibrous feedstuffs in the small intestine and total digestive tract of ponies. British Journal of Nutrition, v.88, p.729-740, 2002.

MORGADO, E.S.; ALMEIDA, F.Q.; SILVA, V.P. et al. Digestão dos carboidratos de alimentos volumosos em equinos. Revista Brasileira de Zootecnia, v.38, n.1, p.75-81, 2009.

NATIONAL RESEARCH COUNCIL - NRC. Nutrient requirements of horses. 5.ed. Washington, D.C., National Academies Press, 1989. $100 \mathrm{p}$.

NATIONAL RESEARCH COUNCIL - NRC. Nutrient requirements of horses. 6.ed. Washington, D.C., National Academies Press, 2007. $341 \mathrm{p}$.

ØRSKOV, E.R. The in situ technique for the estimation of forage degradability in ruminants. In: GIVENS, D.I.; OWEN, E.; AXFORD, R.F.E et al. (Eds.) Forage evaluation in ruminant nutrition. CABI Publishing, 2000. p.175-188.

ØRSKOV, E.R.; McDONALD, I. The estimation of protein degradability in the rumen from incubated measurements weighted according to rate of passage. Journal of Agricultural Science, v.92, p.499-503, 1979.

PÉREZ, P.; RINCÓN, A.; CIPAGOUTA, M. et al. Marquenque (Desmodium heterocarpon (L.) DC. Subs. Ovalifolium (Prain.) ohashi CIAT 13651. Leguminosa de usos múltiples em sistemas agropecuários em Colômbia. CIAT, 2002. 27p.

RIBEIRO, K.G.; PEREIRA, O.G.; VALADARES FILHO, S.C. et al. Caracterização das frações que constituem as proteínas e os carboidratos e respectivas taxas de digestão, do feno de capim Tifton-85 de diferentes idades de rebrota. Revista Brasileira de Zootecnia, v.30, n.2, p.589-595, 2001.

STEFANSDOTTIR, G.J.; HYSLOP, J.J.; CUDDEFORD, D. The in situ degradation of four concentrate foods in the caecum of ponies. In: BRITISH SOCIETY OF ANIMAL SCIENCE MEETING, 112., 1996, Scarborough. Proceedings... Scarborough: BSAS, 1996. p.621.

UDÉN, P.; VAN SOEST, P.J. Investigations of the in situ bag technique and a comparison of the fermentation in heifers, sheep, ponies and rabbits. Journal of Animal Science, v.58, n.1, p.213-221, 1984.

UNIVERSIDADE FEDERAL DE VIÇOSA. SAEG - Sistema de análises estatísticas e genéticas. Versão 8.0. Viçosa, MG: Universidade Federal de Viçosa, 2000. (Manual do usuário). $150 \mathrm{p}$.

VAN SOEST, P.J. Nutritional ecology of the ruminant. 2.ed. Cornell University Press, 1994. 475p.

VAN SOEST, P.J.; ROBERTSON, J.P.; LEWIS, B.A. Methods for dietary fiber, neutral detergent fiber, and nonstarch polysaccharides in relation to animal nutrition. Journal of Dairy Science, v.74, p.3583-3597, 1991

VELOSO, C.M.; RODRIGUEZ, N.M.; CARVALHO, G.G.P. et al. Degradabilidade ruminal da matéria seca e da proteína bruta de folhas e folíolos de forrageiras tropicais. Revista Brasileira de Zootecnia, v.35, n.2, p.613-617, 2006.

WELYENBERG, S.V.; SALES, J.; JANSSENS, G.P.J. Passage rate of digesta through the equine gastrointestinal tract: A review. Livestock Science, n.1, v.99, p.3-12, 2006. 